\title{
Comparison of the efficacy of written information vs. verbal plus written information in rheumatic patients who receive colchicine treatment
}

\author{
Fatma Ilknur Cinar (*), Nuran Tosun (*), Nalan Akbayrak (*), Ismail Simsek (**), \\ Muhammet Cinar $\left({ }^{* *}\right)$, Hakan Erdem $\left({ }^{* *}\right)$, Salih Pay $\left({ }^{* *}\right)$, Selim Kilic $\left({ }^{* * *}\right)$, Sedat Yilmaz $\left({ }^{* *}\right)$, \\ Sevim Cetinkaya $\left(^{* *}\right)$, Ayhan Dinc $\left(^{* *}\right)$
}

\begin{abstract}
This study was planned to compare the efficacy of written information vs verbal plus written information in patients with rheumatic diseases who receive colchicine treatment. Initially, a readable and comprehensible "drug information booklet" was developed for the patients. After that, a "drug knowledge questionnaire" was structured for testing to assess the level of patients' knowledge. The questionnaire was responded by the patients (Pretest). Seventy one patients were categorized into two groups; Group A $(n=35)$ consisted of patients given only the written booklet, whereas patients given verbal information along with the written booklet included in Group B $(n=36)$. To assess the level of knowledge at 8-12-week after, the same questionnaire was asked again (Posttest). As expected, compared to baseline, there was a significant increase in the knowledge levels of the patients following both form of education $(p<0.001)$; however knowledge levels did not show significant differences between the groups $(p=0.426)$. This study showed that patient education is successful in increasing the knowledge levels of patients, irrespective of methods being used for informing. So, a written drug information booklet alone seems to be a useful tool to increase awareness of patients about a certain medication.
\end{abstract}

Key words: Drug information booklet, Knowledge, Verbal information, Colchicine

\section{ÖZET}

Kolşisin tedavisi alan romatoloji hastalarında yazılı bilgilendirmeye karşı yazılı ve sözel bilgilendirmenin etkinliğinin karşılaştırılması

Bu çalışma, kolşisin tedavisi alan romatoloji hastalarında yazılı ve sözel bilgilendirme ile yalnız yazılı bilgilendirmenin etkinliğinin değerlendirilmesi amacıyla planlanmış ve uygulanmıştır. Öncelikle hastalar tarafından okunabilir ve anlaşılabilir "ilaç bilgilendirme broşürü", sonra "Hasta bilgi düzeyini değerlendirme anketi" oluşturulmuş ve hastalara uygulanmışıı (Pretest)". Daha sonra hastalar grup $A(n=35)$ ve grup $B(n=36)$ olarak iki gruba ayrılmış, A grubuna sadece "ilaç bilgilendirme broşürü" verilmiş, $B$ grubuna ise sözel bilgilendirme ile birlikte "ilaç bilgilendirme broşürü" verilmiş̧ir. Eğitimlerden 8-12 hafta sonra "Hasta bilgi düzeyini değerlendirme anketi (Posttest)" tekrar uygulanmıştır. Çalışma sonuçlarına göre; hastaların bilgi seviyelerinde anlamlı artış görülmüş ( $p<0.001)$, ancak gruplar arasında bilgi seviyeleri bakımından anlamlı fark oluşmamıştı $(\mathrm{p}=0.426)$. Yazılı ve sözel bilgilendirmenin bir arada kullanıldı̆̆ı eğitim seklinin hastaların bilgi seviyelerini arttırmada daha başarılı olduğ beklenmekle birlikte sonuçlarımız iyi hazırlanmış bir yazıı broşürün de yalnız başına faydalı olabileceğini göstermektedir.

Anahtar kelimeler: Ilaç bilgilendirme broşürü, Bilgi, sözel bilgilendirme, Kolşisin

* Gulhane Military Medical Academy, School of Nursing,

** Gulhane Military Medical Academy School of Medicine, Division of Rheumatology,

*** Department of Epidemiology and Public Health, Ankara, Turkey

The present study was presented as an oral presentation at the Annual European Congress of Rheumatology (10-13 JUNE 2009; Copenhagen)

Reprint request: Dr. Fatma İlknur Çınar, Gülhane Askeri Tıp Akademisi Hemşirelik Yüksek Okulu, 06010, Etlik, Ankara, Türkiye

E-mail: icinar@gata.edu.tr@hotmail.com

Date submitted: April 10, 2012 • Date accepted: June 04, 2012 • Online publication date: June 27, 2013

\section{Introduction}

In recent years, one of the most notable changes occurred in health care system is the increase in the patients' desires to be included in their decision process. Besides, every patient has right to have satisfying knowledge about their disease and medications planned to be received. On the other hand, patients often believe that they are not fully informed about the details of their treatment and they also want to be informed about their medical situation (1).

Good information about medicines is important for enabling patients to understand their options and express preferences for informed decision making (2). Providing information to the patients about their illness and treatment is an important part of the patient management. Information is particularly important for those who are diagnosed with chronic and requiring long standing treatment diseases such as rheumatic disorders $(3,4)$. Efficient treatment of rheumatic diseases mainly requires patients' self-care and this can only be provided with certain information. Unfortunately, studies have shown that $(1,5)$ patients are not fully informed about their disease and the drugs they use (6). The most important gain of the correct training of the patient is to increase the adaptation to the treatment. Collaboration of nurses and other medical staff with the doctor is very important for providing the patient with correct information. The patients may have many questions about the treatment and their disease. Providing the training material and information required to answer these questions appropriately as well as being properly informed themselves about the disease is the responsibility of all medical staff. 
Correct preparation and training of the patient and effective communication are very important to increase the adaptation to the treatment (7). Patient education regarding the drugs in use can be given either verbally or written, as well as both measures can be used together. Many health professionals rely on verbal information, but this has been shown to be ineffective; patients tend to forget approximately half of the information they are given verbally in a short time (3). On the other hand, written information has been shown to increase patients' knowledge about their drugs, and knowledge is retained over a longer period $(8,9)$. Especially when the patients are hospitalized for short time, written patient information booklets can be valuable means of communication and may support the training and verbal information $(6,10)$.

Behcet's disease (11) and familial Mediterranean fever (FMF) (12) are common rheumatologic diseases among Turkish population. Colchicine is currently being used with a chronic stable prophylactic dose to prevent relapses or attacks in both of those diseases. In rheumatology practice, several drug information booklets (DIBs) have been developed and tested in several clinical settings and various populations $(3,13)$. But, there is no previous study investigating the effectiveness of colchicine drug information booklet. Therefore developing a readable and comprehensible drug information booklet (DIB) for colchicine is important.

A project has been started in our rheumatology division in order to evaluate the effectiveness of several DIBs which are currently in use and to implement the use of these booklets for patient training. As a part of that ongoing project the aim of the present study is to evaluate the effectiveness of DIB for colchicine. Therefore, this study was planned to compare the efficacy of written information vs verbal plus written information in patients with rheumatic diseases who receive colchicine treatment.

\section{Materials and Methods}

This quasi-experimental study was conducted in our rheumatology clinic between the June 2008 and February 2009. Patients who had a diagnosis of FMF, Behcet's disease or gout, and supposed to use colchicine for more than 12 weeks, were included to the study. Patients invited to the study have not been informed formally about the drug previously, either in written or verbal manner. Some was already being on colchicines while others were newly being commenced colchicine. Although, physicians usually inform the patient about the drug when they start a new treatment, and all patients take a drug information sheet that comes routinely with the drug, in this study, patients who were already on colchicine reported that they did not have been informed formally about the drug previously. Patients who did not accept to participate in the study and who did not able to read the drug information booklet were excluded. All gave their written informed consents. The approval required to conduct the study was obtained from the local Ethics Committee.

The colchicine DIB that has been in routine use was updated by a team consisting of physicians and clinical training nurses. The booklet was designed to provide general information about the drug, to raise awareness and to emphasize the importance of the regular use of this drug. The language used in the booklet was plain and simple so that the patients can understand the information. Before the primary study was undertaken, 2 preliminary studies were carried out. In preliminary study 1 , legibility and comprehensibility of the booklet and incoherent parts were assessed. Ten consecutive patients attending the rheumatology clinic who had been newly prescribed colchicine read the existing DIB intended for use in the primary study; with feedbacks several revisions were made on DIB that render information easier to read. After all, following the agreement on the content of the draft by all patients, the booklet was then revised accordingly and took its final form. The information topics in the booklet were including ingredients, mechanism of effect, side effects, monitoring, etc. Main contents of the booklet are given in Box I.

\section{Box I. Key areas of information outlined in the colchicine information booklet}

- An explanation about active ingredient, various names and forms of colchicines and method of application

- An outline of how does the drug work

- Brief explanation about the intended use of the drug for rheumatic disease

- The important points to be considered before the drug is used

- Required knowledge about the usage of the drug

- Contraindication of the medication 
- The side-effects of the colchicine

- Knowledge about the required follow-ups for the patients during medication

- The rare conditions to be taken into consideration while the drug is being used

- Safe storage of drug

Later, in preliminary study 2 , a drug knowledge questionnaire (DKQ) was developed for testing to assess the education level of patients. DKQ comprised 10 multiple-choice questions which correspond to ten topics in the booklet with a choice of 5 responses. Specific areas from the DIB were identified for testing in the questionnaire and it was make sure that all 10 correct answers could be found in the colchicine DIB. The questionnaire was tested on 10 patients none experienced problems with its readability or layout, and all thought that the DIB answered all the questions on the DKQ. Each correct answer was calculated as ten points, so total score of the test was 100 points. That questionnaire was given to 10 patients to show the comprehensibility and feasibility of the survey items. Then the questionnaire took its final form.

In the primary study, total of 71 patients who had been followed at the rheumatology clinic or outpatient service fulfilling the mentioned inclusion criteria were assigned to the study. Demographic and clinical data (age, gender, educational background, disease, disease duration, number of currently used drugs, and the interval on colchicine) of the patients was collected. Initially, a DKQ consists of 10 questions was performed to all patients (Pretest). Next, the patients were randomized (1:1) to one of two groups according to order of arrival to the hospital; Group A $(n=35)$ consisted of patients given only the written booklet, whereas patients given verbal information along with the written booklet included in Group B $(\mathrm{n}=36)$.

The information provided through verbal education mainly based on the content of the booklet by nurse researchers. The education was given to patients faceto-face, and slide presentation and booklet developed for colchicine were used during the education. During the verbal sessions the questions raised by the patients were also answered. The instruction sessions were lasted for approximately 30-45 minutes, done as either outpatient or inpatient setting. At the end of the study, 8-12 weeks after those steps, DKQ was applied to all participants again (Posttest). Study design is given in Figure 1.

\section{Statistical Analysis}

SPSS for Windows Ver. 15.00 (SPSS Inc., Chicago, IL., USA) software was used for statistical analysis. Compatibility of the continuous data with the normal distribution was examined with the ShapiroWilk test. Descriptive statistics were presented either as median (min-max), or as frequency. Categorical data was compared with chi-square or Fisher's exact test as appropriate and continuous data was with Mann Whitney U test. Results of the assessments both before and after the intervention were standardized to the scale of 100 points. The difference between pre and post intervention DKQ scores for both groups were compared with Wilcoxon signed rank test and the difference between two groups for pre and post intervention DKQ scores of were compared with Mann Whitney U test. Chi-square test was used for determining the differences between pre and post intervention DKQ scores for both groups and McNemar bowker test was used difference between two treatment groups for pre and post intervention for each question. In statistical analysis, $\mathrm{p} \leq 0.05$ level was deemed as an indicator of a significant difference.

\section{Results}

Of the all (71) patients, 62 patients $(87.3 \%)$ were male. In Group A $(n=35)$ patients' median age was 22.00 (21.0-44.0), median disease duration was 4.00 (2.0-18.0) years, median duration of colchicine use was 4.00 (1.0-18.0) years, median number of the drugs used was 1.00 (1.0-7.0). In Group B $(n=36)$ patients' median age was 22.50 (21.0-58.0) years, median

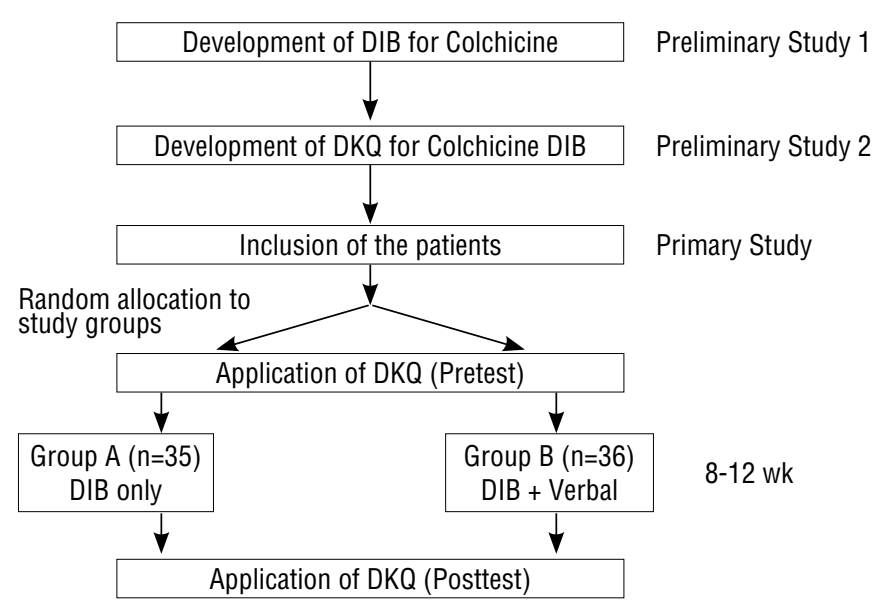

Figure 1. Study design. DIB drug information booklet. DKQ drug knowledge questionnaire. 
disease duration was 5.00 (2.0-34.0) years, median duration of colchicine use was 3.00 (2.0-20.0) years, median number of the drugs used was 1.00 (1.0-7.0). No significant differences were observed between the groups in terms of those characteristics $(p>0.05)$. Characteristics of the patients; included in the study are represented in Table I.

In both groups, a significant increase was observed in the knowledge scores at the posttest assessment carried out 8-12 weeks after the education sessions when compared to corresponding pretest results $(\mathrm{p}<0.001)$. However, no significant statistical differences were observed between the groups $(\mathrm{p}=0.426)$ (Table II).

To evaluate the difference between the groups, percentage values of those who provided 6 or more correct answers after 8-12 weeks were examined. The percentages of patients were $80.0 \%$ and $91.7 \%$ for Group A and B respectively. Although this difference was not statistically significant $(\mathrm{p}=0.189)$, it seemed that Group B had better values.

For each question in both groups, a significant increase was observed in the correct answers (except question 6) at the posttest assessment when compared to corresponding pretest results $(\mathrm{p}<0.05)$. However, no significant statistical differences were observed between the groups (except question 8) $(\mathrm{p}>0.05)$ (Table III).

\section{Discussion}

This study was conducted in order to compare the efficacy of written information and verbal plus written information in patients with rheumatic diseases who were receiving colchicine treatment. The study has

Tablo I. Characteristics of the patients $(n=71)$.

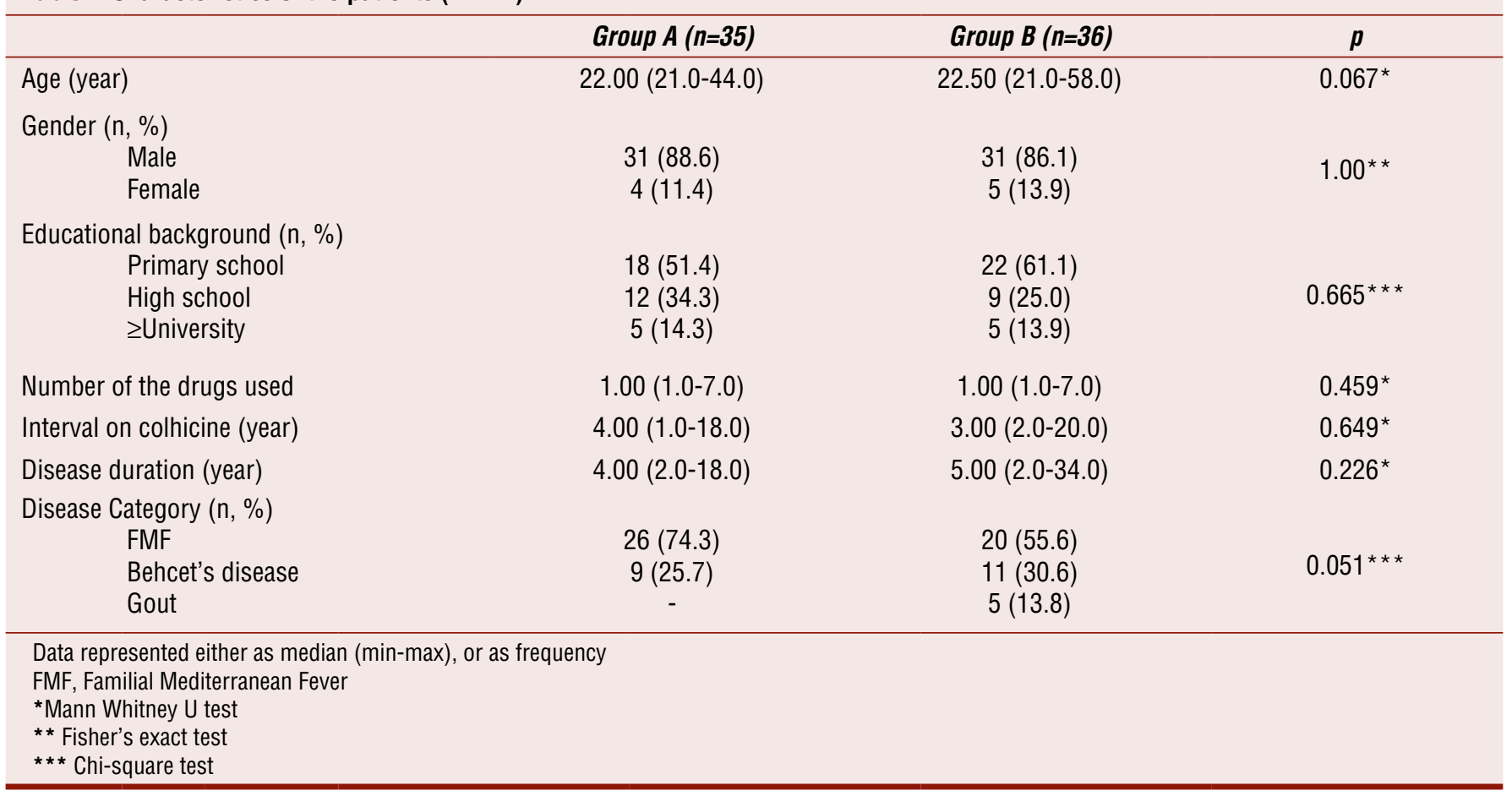

Tablo II. Comparison of the knowledge scores of written information alone (Group A) and verbal plus written information (Group B).

\begin{tabular}{lccc}
\hline & Group $\boldsymbol{A}(\boldsymbol{n}=\mathbf{3 5})$ & Group $\boldsymbol{B}(\boldsymbol{n}=\mathbf{3 6})$ & $\boldsymbol{p}^{* *}$ \\
\hline Pre-test DKQ score & $30.00(0.0-70.0)$ & $30.00(0.0-70.0)$ & 0.848 \\
Post-test DKQ score & $70.00(20.0-100.0)$ & $70.00(0.0-100.0)$ & 0.426 \\
Difference & $40(-10 / 70)$ & $40(0 / 80)$ & 0.576 \\
\hline $\boldsymbol{p}^{*}$ & $<\mathbf{0 . 0 0 1}$ & $<\mathbf{0 . 0 0 1}$ & \\
\hline DKQ, Drug knowledge questionnaire. Values are represented as median (min-max) & & \\
$\boldsymbol{p}^{*}$ Wilcoxon signed rank test & & \\
$\boldsymbol{p}^{* *}$ Mann-Whitney U test & & \\
\hline
\end{tabular}




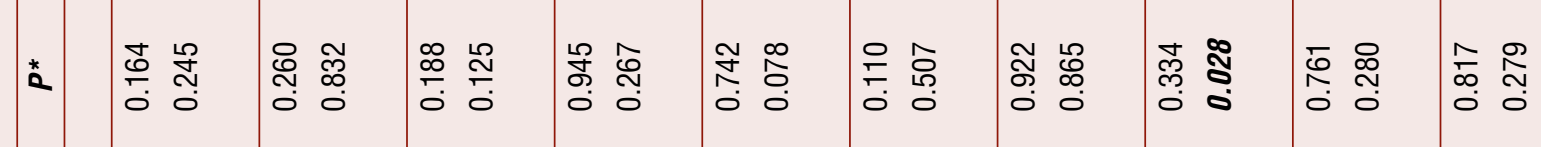

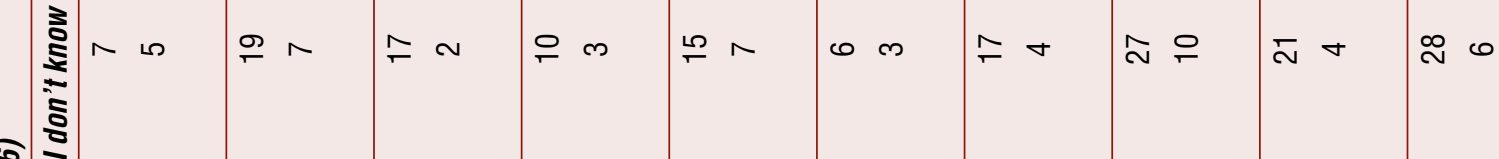

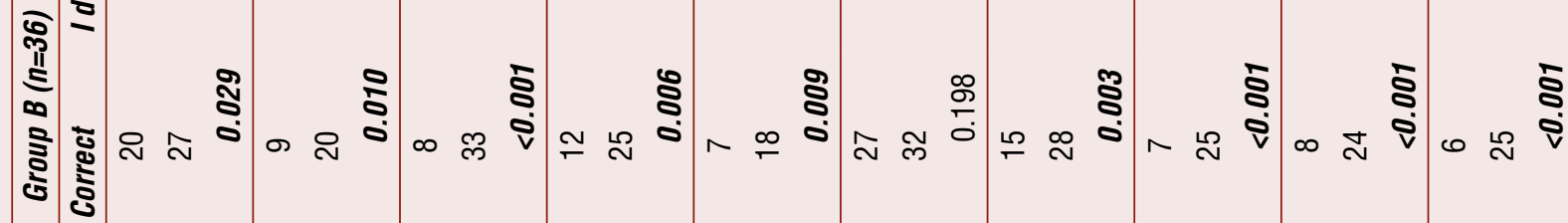

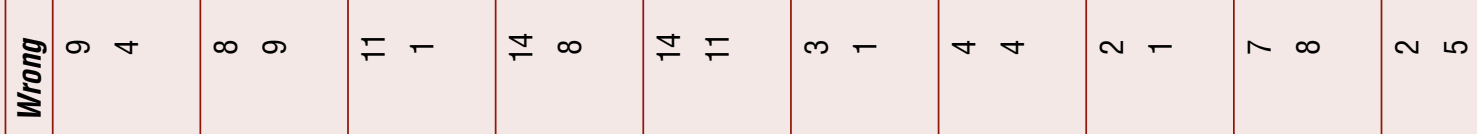

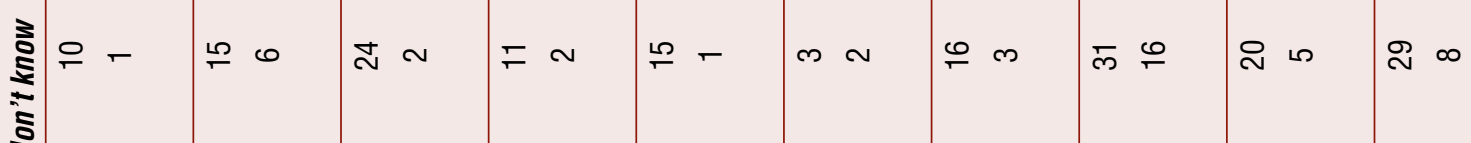

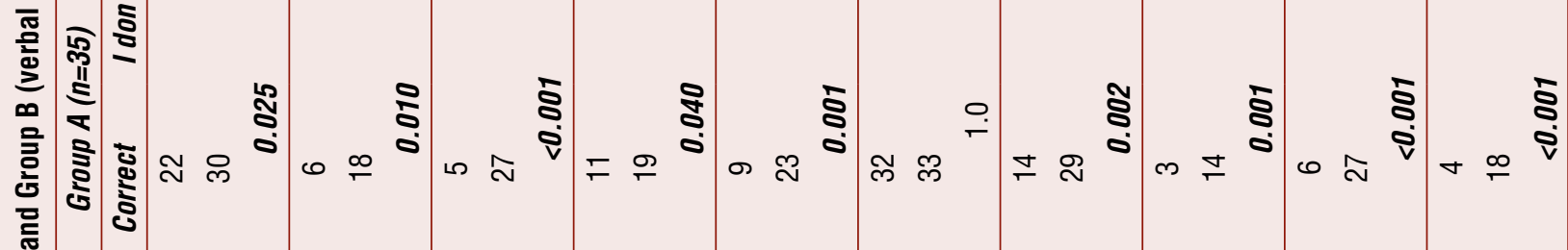

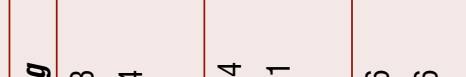

$\stackrel{F}{P}=\mp$

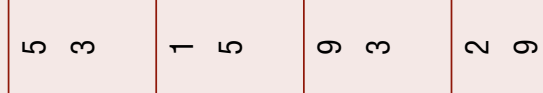
sิ

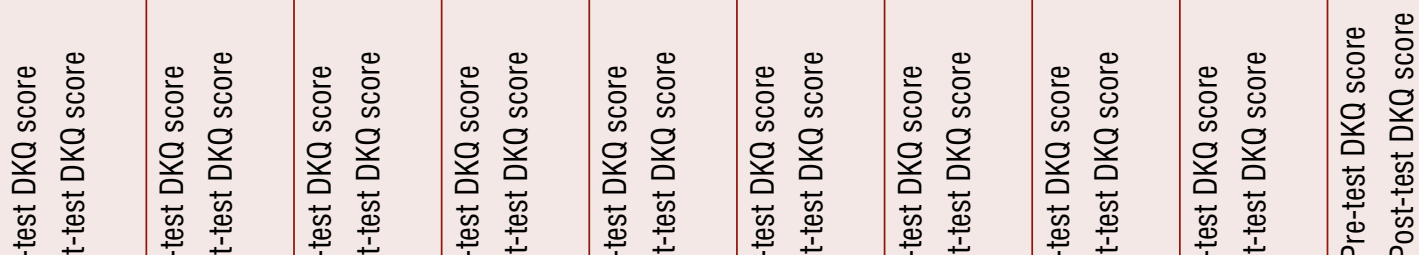

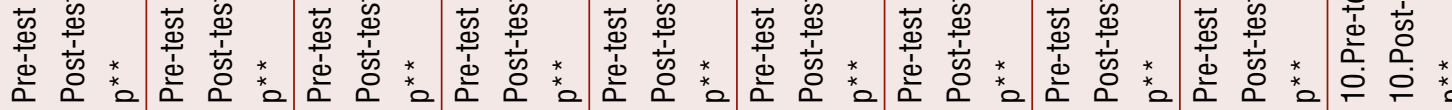
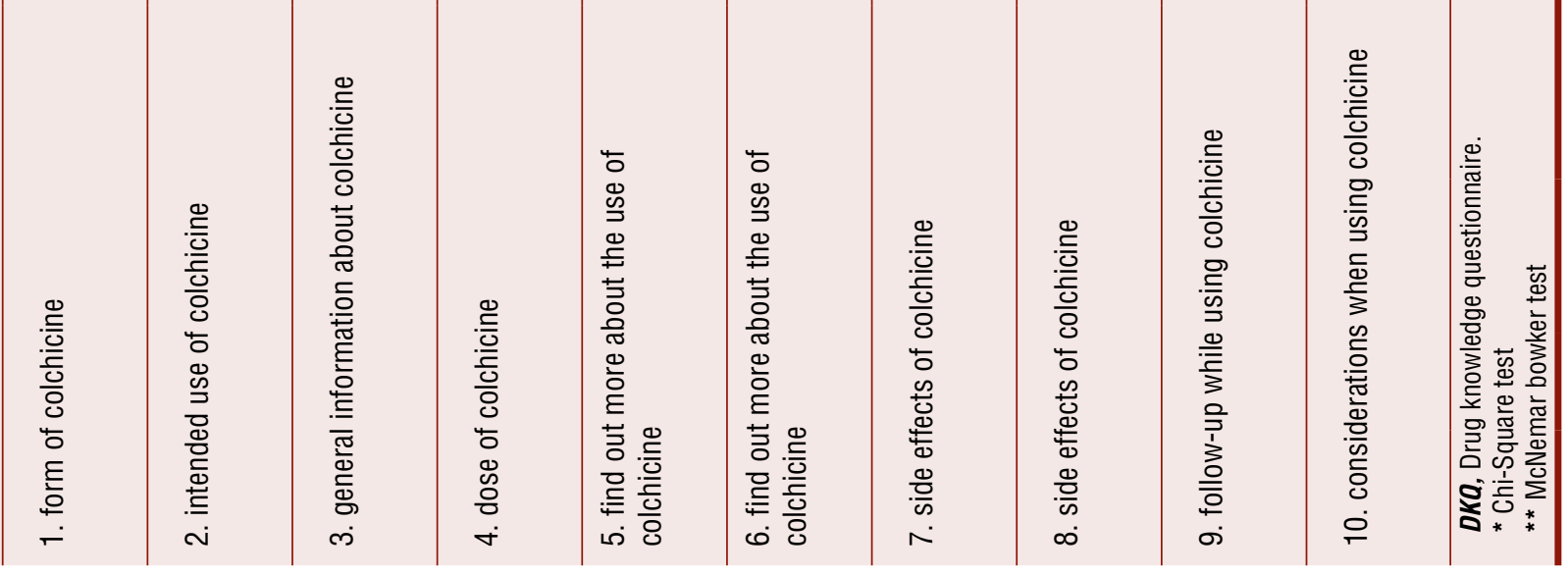
demonstrated that, there was a significant increase in the knowledge levels of the patients. However there was not a significant difference regarding the information levels between the groups. Similarly, when each question is considered separately, there was no significant difference in answer frequencies between the groups generally. Although training method where written and verbal information are collectively used was expected to be more successful in increasing the knowledge levels of patients, our study showed that a well-prepared drug information booklet alone can also be useful.

Similar results have been obtained in previous studies conducted in various settings $(3,13,14)$. In one study, the rheumatology patients using non-steroid anti-inflammatory drugs were divided into three groups: booklet, booklet plus verbal information and only verbal information groups; and as a result of the provided training, no significant differences were observed with respect to the information levels. The results of the same study also showed that either written or verbal, the provided trainings do create an increase in the information levels of patients or that providing the patient group with information booklets is very useful (13). Similarly, Hill and Bird detected that informing rheumatology patients using d-penicillamine with verbal information in addition to written information booklets create an increase in the information levels of the patients however; they did not observe significant differences between groups (3).

Written information is an important component of patient-centered care as it helps patients to make informed choices about their healthcare (14). Written information not only influenced respondents' decisions to start or continue taking a medicine, it was also needed to prepare patients for what they might experience in response to a drug. ${ }^{2}$ Providing drug information with booklets has been shown to be helpful to patients, but if they aren't prepared well they also cause some concerns (15). They are only useful if the patient is able to read and understand them, otherwise they may become an expensive waste of resources. Authors emphasized that information that was provided with simple statements and without details is a key point $(3,6,13,14,16)$. For this reason easily readable and comprehensible patient information booklets could be very effective in increasing the patients' knowledge.
The researches show that the patients forget the half of the verbally provided information in five minutes, and also they can remember only $20 \%$ of the provided information. However, when the verbal information is supported with written information, this rate can increase up to $50 \%(3,9)$. Providing the patients and their families with written information may reduce anxiety, improve use of preventative or self-care measures, increase adherence to treatment, prevents communication problems between health care providers and patients, lead to more appropriate and effective use of health care services, and helps reducing the costs thereby $(17,18)$. Some of the studies which have evaluated written information have looked at recall, compliance (10), behavioral changes (19), and adherence to the treatment (18). Nair et al. state that patients need to be provided with information about their medications and they emphasize that giving information on used drugs is very important to increase the patients' compatibility with the treatment (1). In another study about adherence showed that behavioral changes did occur after education, and patients who were provided with information were significantly more adherent to their drug therapy (19). But these mentioned conditions were not tested separately in our study. It is possible that similar positive effects may be accessible if the patients are provided adequate knowledge about their medications.

Although additional verbal explanation of colchicine enhanced patient knowledge, it did not reach statistical significance in our study. One and more likely reason for the lack of enhancement in this study is that the questions on the colchicine knowledge questionnaire were designed specifically from the information provided on the DIB. Finally it may well be that an additional verbal explanation simply did not furnish the patients with a significant amount of further information. However verbal information has many advantages. During verbal information, the patients had the opportunity to review the unclear data, to establish more friendly relationships and to correct the misunderstandings which were not tested in this study. In general, it is supported in literature that written and verbal information should be given collectively. It is reported that combination of verbal and written information is the ideal for providing information to the patients. Thus, in that way patients maximize 
recall and understanding, and it is preferred by patients $(3,13,14,16)$.

In summary colchicine DIB that was developed at our unit is a highly effective method of increasing the patient's knowledge of the colchicine. But, written and verbal information should be given collectively, where possible.

\section{Limitations}

This study is limited by the inability to generalize the study results to whole group of rheumatic patients since the study was conducted on limited number of participants. Although during the verbal information patients have the opportunity to ask questions repeatedly the adequacy of training of a period of 3540 minutes can be discussed. In our study it is not evaluated whether the duration of education affect study results or not.

\section{Acknowledgements}

The authors thank clinical members of the Division of Rheumatology, Gulhane School of Medicine, for assistance with the conduct of the study.

\section{References}

1. Nair K, Dolovich L, Cassels A, et al. What patients want to know about their medications. Focus group study of patient and clinician perspectives. Can Fam Physician 2002; 48: 104-110.

2. Raynor DK, Blenkinsopp A, Knapp P, et al. A systematic review of quantitative and qualitative research on the role and effectiveness of written information available to patients about individual medicines. Health Technol Assess 2007;11(5): iii, 1-160.

3. Hill J, Bird H. The development and evaluation of a drug information leaflet for patients with rheumatoid arthritis. Rheumatology (Oxford) 2003; 42(1): 66-70.

4. Ansani NT, Fedutes-Henderson BA, Weber RJ, et al. The drug information center arthritis project: Providing patients with interactive and reliable arthritis internet education. Drug Information Journal 2006; 40(1): 3949.

5. Wilson M. Readability and patient education materials used for low-income populations. Clin Nurse Spec 2009; 23(1): 33-40; quiz 41-42.
6. Mumford ME. A descriptive study of the readability of patient information leaflets designed by nurses. J Adv Nurs 1997; 26(5): 985-991.

7. Vizcarra C, Belcher D. Management of the patient receiving parenteral biologic therapy. J Infus Nurs 2006; 29(2): 63-71.

8. Harris M, Smith B, Veale A. Printed patient education interventions to facilitate shared management of chronic disease: A literature review. Intern Med J 2005; 35(12): 711-716.

9. Barlow JH, Wright CC. Knowledge in patients with rheumatoid arthritis: A longer term follow-up of a randomized controlled study of patient education leaflets. Br J Rheumatol 1998; 37(4): 373-376.

10. Ashraff S, Malawa G, Dolan T, Khanduja V. Prospective randomised controlled trial on the role of patient information leaflets in obtaining informed consent. ANZ J Surg 2006; 76(3): 139-141.

11. Yazici H. Behçet's syndrome: An update. Curr Rheumatol Rep 2003; 5(3): 195-199.

12. Onen F. Familial Mediterranean fever. Rheumatol Int 2006; 26(6): 489-496.

13. Arthur V, Clifford C. Evaluation of information given to rheumatology patients using non-steroidal antiinflammatory drugs. J Clin Nurs 1998; 7(2): 175-181.

14. Felley C, Perneger TV, Goulet I, et al. Combined written and oral information prior to gastrointestinal endoscopy compared with oral information alone: A randomized trial. BMC Gastroenterol 2008; 8: 22.

15. Oldman M, Moore D, Collins S. Drug patient information leaflets in anaesthesia: Effect on anxiety and patient satisfaction. Br J Anaesth 2004; 92(6): 854-858.

16. Koo M, Krass I, Aslani P. Enhancing patient education about medicines: Factors influencing reading and seeking of written medicine information. Health Expect 2006; 9(2): 174-187.

17. Moult B, Franck LS, Brady H. Ensuring quality information for patients: development and preliminary validation of a new instrument to improve the quality of written health care information. Health Expect 2004; 7(2): 165-175.

18. Ulfvarson J, Bardage C, Wredling RA, von Bahr C, Adami J. Adherence to drug treatment in association with how the patient perceives care and information on drugs. J Clin Nurs 2007; 16(1): 141-148.

19. Hill J, Bird H, Johnson S. Effect of patient education on adherence to drug treatment for rheumatoid arthritis: a randomised controlled trial. Ann Rheum Dis 2001; 60(9): 869-875. 